\section{Aksi Masyarakat Peduli Sanitasi Dalam Mewujudkan Kampung Hijau Di Cempaka Putih, Jakarta Pusat}

\author{
Yugni Maulana Aziz ${ }^{1)}$, Naufal \\ Muzaki Setiawan ${ }^{2)}$, M Dian \\ Hikmawan $^{3)}$ \\ 1) Program Studi Ilmu Pemerintahan, \\ Universitas Sultan Ageng Tirtayasa. \\ Banten, Indonesia. \\ 2) Program Studi Ilmu Pemerintahan, \\ Universitas Sultan Ageng Tirtayasa. \\ Banten, Indonesia. \\ 3) Program Studi Ilmu Pemerintahan, \\ Universitas Sultan Ageng Tirtayasa. \\ Banten, Indonesia.
}
*Korespondensi Penulis E-mail: dian.hikmawan@untirta.ac.id

\begin{abstract}
DKI Jakarta setiap hari memproduksi 7000 ton sampah, hal itu merupakan masalah lingkungan yang perlu ditangani secara serius karena berdampak pada semua sektor. Kampung Hijau berseri menjadi salah satu kampung percontohan bagi masyarakat Jakarta Pusat sebagai kampung pengurangan sampah dari Pemprov DKI Jakarta karena kegiatan yang di lakukan warganya berusaha mengurangi jumlah sampah yang di setor ke TPA (Tempat Pembuangan Akhir). AMPUTASI (Aksi Masyarakat Peduli Sanitasi) melakukan gerakan bersama masyarakat Kampung Hijau Berseri untuk melakukan tindakan nyata mengurangi hasil produksi sampah Jakarta dengan cara memilah sampah organic dan non organic. Penelitian ini dilakukan di Kampung Hijau Berseri dengan menggunakan teknik wawancara dan observsi. Jenis penelitian yang di gunakan dalam penelitian ini menggunakan metode kualitatif. Penelitian
\end{abstract}

ini menemukan gerakan AMPUTASI mengurangi jumlah sampah dengan cara membuat sampah lebih memiliki nilai ekonomis.

Kata kunci: Jakarta, Sampah, Kampung Hijau Berseri, AMPUTASI

\section{Community Action of Sanitation Care In Developing Green Village In Cempaka Putih, Central Jakarta}

\begin{abstract}
DKI Jakarta produces 7000 tons of waste every day, this is an environmental problem that needs to be solved seriously because it affects all sectors. Green Village become one of the best Village practice for the people of Central Jakarta as a waste reduction village from DKI Jakarta Provincial Goverment, because the activities carried out by its citizens try to reduce the amount of waste deposited in the Final Disposal Site (TPA), AMPUTASI (Aksi Masyarakat Peduli Sanitasi) act collective action with Green Village society to do real action on reducing Jakarta waste production by sorting out organic and non-organic waste. This research was done in Green Village using interview and observation techniques. This research used qualitative methode with case study approach, this article find out AMPUTASI movement aim to reduce the amount of rubbish heap with making it have more economic value.
\end{abstract}

Keywords: Jakarta, rubbish, Green Village, AMPUTASI 


\section{A. PENDAHULUAN}

Meningkatnya

produktifitas

sampah memberikan dampak buruk yang signifikan terhadap lingkungan hal ini dikerenakan, masih banyaknya masyarakat yang belum sadar akan pengelolaan sampah yang baik. Terlebih lagi sampah yang menumpuk dipenuhi oleh sampah plastik hal ini akan semakin memperburuk kondisi lingkungan. DKI Jakarat merupakan salah satu kota di Indonesia yang memiliki masalah sampah yang serius.

Permasalahan sampah di DKI Jakarta membuat Jakarta menjadi wilayah berpotensi darurat sampah hal itu terjadi karena Jakarta memproduksi 7000 ton setiap harinya karena tingkat penduduk yang sangat padat bahkan penelitian Oxford Economics dalam Laporan Global Cities 2018 menyebutkan bahwa Jakarta akan menjadi kota terpadat di dunia pada tahun 2035 sebanyak 38 juta jiwa melebihi Tokyo yang hanya 37.8 juta jiwa dan masyarakat yang datang ke Jakarta sangat majemuk yang berasal dari berbagai daerah dengan latar belakang kebudayaan sehingga tidak bisa di pungkiri bahwa kemajemukan ini menyulitkan pemerintah untuk mengatur masyarakat Jakarta, bahkan sampah yang di produksi oleh masyarakat Jakarta sebanyak itu akhirnya menyebar ke berbagai tempat sehingga satu penyebab sampah menyebabkan masalah yang lain terjadi kemudian menimbulkan multilevel problem, bahkan gubernur DKI Jakarta menyebutkan salah satu prioritas pembangunan di Jakarta adalah air bersih karena masih ada
40\% warga DKI Jakarta masih belum menikmati pelayanan air bersih yang di sebabkan salah satunya produksi sampah yang begitu sangat banyak sehingga pengelolaan sampah sangat tidak terelakan dan dibutuhkan dari semua pihak baik pemerintah maupun masyarakat untuk melakukan perbaikan Jakarta terutama dalam hal pengelolaan sampah yang di hasilkan oleh masyarakat Jakarta, karena penimbunan sampah yang tidak di olah dengan baik akan mencemari tanah secara langsung serta mengakibatkan menurunya kualitas air permukaan dan air tanah, namun tugas pengolalaan sampah tidak hanya menjadi tugas pemerintah di butuhkan juga pergerakan dari masyarakat seperti yang di lakukan masyarakat di Kampung Hijau Berseri (Bersih, Sehat, Asri), Cempaka Putih Timur, Jakarta Pusat dalam mengolah sampah untuk mengatasi memuncaknya produksi sampah Jakarta sehingga membentuklah satu kesatuan aksi masyarakat untuk mengurangi setoran sampah ke tempat pembuangan akhir sampah.

AMPUTASI merupakan sebuah aksi masyarakat Kampung Cempaka Putih Timur yang melihat masalah sampah yang sangat berlebih di Jakarta terkhusus sangat prihatin melihat warga Jakarta tidak mendapatkan pelayanan air bersih sebanyak $40 \%$ sehingga masyarakat Jakarta belum merasakan air bersih seutuhnya bahkan menurut data dari PAM Jaya, Jakarta hanya menghasilkan 20.000 liter per detik lalu mengalami penurunan tingkat kehilangan air yang 
mencapai 43\% untuk kebutuhan masyarakat dengan luas wilayah penduduk sebesar $661,5 \mathrm{~km}^{2}$ itu sangat tidak cukup dan membutuhkan pasokan air tambahan dari resapan air tanah itupun dengan komposisi yang seimbang dan tidak boleh berlebih sebab akan menghasilkan masalah penurunan permukaan tanah 2 sampai 13 sentimeter per tahun artinya hal ini menjadi masalah sangat fundamental bagi masyarakat sendiri sebab air menjadi bahan paling mendasar bagi kehidupan masyarakat maka dari itu masyarakat melakukan AMPUTASI (Aksi Masyarakat Peduli Sanitasi), aksi ini sendiri di pelopori oleh bapak Aan sebagai Ketua Lembaga Musyawarah Kelurahan melihat keadaan masyarakat kampungnya sendiri tidak menikmati kehidupan bermasyarakat yang sehat namun dengan keadaan yang sangat kumuh penuh dengan sampah yang membawa dampak buruk bagi masyarakat sehingga aksi ini berusaha mengajak masyarakat untuk bersama-sama melakukan perubahan pola kehidupan yang kotor menjadi BERSERI (Bersih, Sehat, Asri) sehingga menjadikan lingkungan masyarakat menjadi lebih baik dari sebelumnya.

Kampung Hijau berseri menjadi salah satu kampung percontohan bagi masyarakat Jakarta Pusat sebagai kampung pengurangan sampah dari Pemprov DKI Jakarta karena kegiatan yang di lakukan warganya berusaha mengurangi jumlah sampah yang di setor ke TPA (Tempat Pembuangan Akhir) sebab kita ketahui bersama bahwa sampah seperti yang di jelaskan sebelumnya menempati posisi yang sangat tidak memberikan keuntungan sama sekali bagi masyarakat namun justru membawa dampak kerugian pada sektor yang lain, untuk itu AMPUTASI (Aksi Masyarakat Peduli Sanitasi) melakukan gerakan bersama masyarakat Kampung Hijau Berseri untuk melakukan tindakan nyata mengurangi hasil produksi sampah Jakarta dengan cara memilah sampah organic dan non organic, sampah organic akan di daur ulang menjadi pupuk untuk tanaman sekitar kampung agar menjadi hijau sesuai misi, sedangkan non organic seperti plastic dan kardus nantinya masuk ke Bank Sampah yang akan di daur ulang menjadi hiasan-hiasan sekitar kampung atau langsung di jual ke pengepul sehingga menghasilkan keuntungan tersendiri bagi masyarakat karena mendapatkan keuntungan secara ekonomis memberikan keungan bagi kas masyarakat untuk melakukan perbaikan demi perbaikan lingkungan, namun berangkat dari aksi masyarakat terhadap pengurangan sampah ternyata kemudian menjadi sinergi dengan kesehatan terhadap lingkungan maka dari itu warga juga membuat resapan air dengan teknik biopori sebagai solusi ketersediaan air bersih sehingga dengan adanya biopori itu sendiri secara langsung memberikan kontribusi bagi prioritas pekerjaan Pemprov DKI Jakarta dalam proses memberikan ketersediaan air bersih bagi masyarakat DKI Jakarta secara khusus bagi masyarakat Cempaka Putih Timur, lalu merambah ke Pertanian Kota menumbuhkan tanaman obat, sayuran dan Kelompok 
Ikan untuk memenuhi kebutuhan dasar masyarakat maka dengan adanya aksi masyarakat dengan cara seperti ini sangat berdampak bagi lingkungan yang lebih baik di sekitaran masyarakat Kampung Hijau Berseri.

Dukungan dari Pemprov DKI Jakarta terhadap AMPUTASI itu sendiri juga sangat berdampak terhadap keberhasilan mewujudukan Kampung Hijau Berseri sebagai kampung percontohan bagi masyarakat Jakarta yang lain sehingga akan sangat berdampak besar jika benar-benar bisa memberikan inspirasi bagi kampung yang di Jakarta ketika semua wilayah di Jakarta mengikuti pola kehidupan yang di lakukan AMPUTASI maka lingkungan masyarakat Jakarta menjadi lebih hijau, bersih dan sehat, mengurangi penyakit yang berasal dari sampah, bahkan menjadikan tanah di Jakarta mampu menyerap air menjadi bersih kembali dan masyarakat Jakarta bisa menikmati air bersih seluruhnya seperti semula yang di hasilkan dari sebuah aksi masyarakat untuk melakukan pola perbaikan kehidupan menjadi lebih bersih seperti yang di lakukan oleh AMPUTASI.

Tujuan penelitian ini ingin melihat bagaimana AMPUTASI sebagai sebuah Aksi Masyarakat Peduli Sanitasi menjadi pelopor bergeraknya masyarakat untuk bersama-sama membangun Kampung Hijau Berseri melalui pendekatan sebuah teori empowerment Chamber yang bersifat peoplecentered, participatory, empowerment and sustainable maka dengan aksi ini masyarakat Kampung Hijau Berseri merasakan kualitas hidup yang jauh lebih baik dan dapat lebih bisa berkontribusi terhadap hasil pembangunan Jakarta sehingga memberikan dampak yang besar bagi kehidupan masyarakat yang lain sebagai kampung percontohan bagi Kampung, Kota bahkan negara lain. Penelitian ini berfokus pada bagaimana peranan AMPUTASI dalam mewujudkan Kampung Hijau Berseri, serta bagaimana dampak yang di rasakan masyarakat Kampung Hijau Berseri dengan adanya AMPUTASI .

Penelitian ini pula memiliki tujuan ilmiah yaitu untuk untuk mengetahui bagaimana Aksi Masyarakat Peduli Sanitasi mewujudkan Kampung Hijau Berseri. Dan bertujuan informatif untuk memberikan informsi kepada khalayak banyak bahwa dibalik banyaknya penumpukan sampah di Jakarta ternyata masih ada kelompok yang peduli terhadap pemberdayaan sampah tersebut.

\section{B. TEORI (Literature Review)}

Pada proses mewujudkan kampung Berseri, Aputasi mencoba untuk memberikan pemahaman kepada warga tentang pengelolaan sampah, dan bagaimana cara memanpaatkan sampah baik yang organic maupun sampah non organik. Dalam hal ini Aputasi memberikan pengethaun tentang cara mendaur ulang sampah yang orgnik menjadi pupuk, dan sampah non organic menjadi hiasan-hiasan kampung atau langsung di jual kepada pengepul. Dengan demikian sampah yang tadinya tidak memiliki niali, bisa dikonversi 
menjadi sebuah barang yang memiliki nilai lebih, dan poin plus nya lagi adalah sampah-sampah yang ada di sekitaran Kampung Indah Berseri, Cempaka Putih Timur, Jakarta Pusat.

Dalam mengkaji permasalahan yang ada, riset ini menggunakan dua teori utama sebagai acuan dalam melihat fenomena Kampung Berseri, yaitu:

\section{Teori Pemberdayaan}

Pemberdayaan berasal dari kata Enpowerement sebagai suatau upaya memberikan wewenang, otonomi, kepada individu atau organisasi untuk melakukan tindakan yang lebih kreatif dan mendorong melaksanakan tugasnya dengan baik, selain itu Priyono (1996) memberikan penjabaran mengenai pemberdayaan suatu pemberian kekuasaan dengan adil untuk meningkatkan kesadaran politis dalam melakukan sesuatu daan memberikan kekuasan kepada suatu kelompok atau individu yang lemah untuk bisa memberikan pengaruh terhadap hasil pembangunan, sedangkan konsep pemberdayaan menurut Friedment (dalam Agus, 2010) mengatakan bahwa pemberdayaan sendiri merupakan pembangunan alternative yang mengutamakan pengembilan keputusan secara otonomi yang berlandaskan, partisipasi masyrakat, sumberdaya pribadi dan bersifat langsung.

Pemberdayaan masyarakat dalam konsep Chamber (dalam Agus, 2010) merupakan pembanguan ekonomi yang merangkum nilai-nilai masyarakat untuk membangun paradigma baru dalam pembangunan yang bersifat peoplecentered, participatory, empowerment and sustainable, Lebih jauh chamber mengatakan bahwa konsep pemberdayaan masyarakat tidak hanya terbatas pada memenuhi kebutuhan dasar namun upaya mencari alternative lain dalam menumbuhkan pertumbuhan local, people centered sebagai human growth yaitu sebuah pembangunan sumber daya manusia agar dapat menjadi Aktor pembangunan yang bisa berpartisipasi, participatory bentuk partisipasi masyarakat dalam segala kegiatan dengan prinsip belajar dengan prinsip orang luar sebagai fasilitator dan masyarakat sebagai pelaku yang saling mengajarkan satu sama lain baik secara formal maupun informal, empowerment sebagai bentuk pemberikan kekuatan kepada yang lemah untuk dapat memberikan kekuatan yang lebih bisa berperan dalam pembangunan dengan konsep tiga aspek penting yaitu enabling dengan menciptakan keadaan masyarakat agar dapat berkembang, empowering memperkuat potensi dan membuka peluang masyarakat agar lebih berdaya dan sustainable yaitu proses pembangunan sumberdaya menusia dengan pendekatan pembangunan manusia dengan orientasi pelayanan sosial dalam memenuhi kebutuhan dasar (basic needs) seperti pendidikan dan peningkatan kesejahteraan masyarakat (Hikmawan, 2017).

Sedangkan menurut Shardlow (dalam Adi, 2008) pemberdayaan masyarakat intinya bagaimana suatu 
individu maupun kelompok memiliki kesadaran dalam mengontrol kehidupan mereka sendiri dan menentukanya. Pemberdayaan merujuk pada kemampuan orang atau kelompok rentan dan lemah sehingga memiliki kekuatan dalam memenuhi kebutuhan dasarnya, menjangkau sumber-sumber produktif yang kemudian memiliki pengaruh terhadap suatu kejadian yang mempengeruhi kehidupanya (Hikmawan, Indriyany, \& Mayrudin, 2019).

Tujuan pemberdayaan menurut Sulistiyani (2004) adalah terbentuknya masyarakat yang mandiri. Kemandirian yang dimaksud adalah mandiri dalam bertindak dan mandiri dalam berpikir sehingga masyakat dapat lebih terbangun untuk melakukan perubahan menuju ke arah yang lebih baik lagi. Lebih lanjut, dengan adanya pemberdaayaan terhadap masyarkat membuat nilai produktifitas masyarakat lebih meningkat (Hikmawan \& Hidayat, 2016).

\section{Teori Kesehatan Lingkungan}

$\begin{array}{crr}\begin{array}{c}\text { Menurut } \\ \text { Organisation }\end{array} & \begin{array}{c}\text { World } \\ \text { (WHO), }\end{array} & \text { suatu }\end{array}$
keseimbanagan ekologi harus bisa terjamin kehadirannya agar dapat menyeimbangkan antara manusia dengan alam, inilah yang kemudian disebut kesehatan lingkungan.

Menurut HAKLI (Himpunan Ahli Kesehatan Lingkungan Indonesia) "Suatu kondisi lingkungan yang mampu menopang keseimbangan ekologi yang dinamis antara manusia dan lingkungannya untuk mendukung tercapainya kualitas hidup manusia yang sehat dan bahagia".

Tolak ukur dalam menilai lingkungan 1) Air Bersih; 2) Pembuangan Kotoran/Tinja; 3) Kesehatan Pemukiman; 4) Pembuangan Sampah; 5) serangga dan Binatang Pengganggu; 6) Makanan dan Minuman.

Dari dua teori tersebut dapat diambil hipotesa sebagai pandangan sementara, bahwa ketika lingkungan ingin terjaga, maka masyarakat yang ada harus memiliki kesadaran yang besar untuk peduli terhadap lingkungan, selain itu bagi masyarakat miskin kota terutama di Jakarta harus mempu melihat peluang yang ada, termasuk dalam memanpaatkan limbah bekas. Jika masyarakatnya berdaya, maka lingkungan yang ada juga akan terjaga, karena sampah yang tadinya merusak lingkungan, sudah bisa dikonversi menajdi barang yang bernilai. Dampaknya adalah tersedianya ari bersih, pemukiman yang sehat, dan tumbuhan hijau.

\section{METODE}

Jenis penelitian yang di gunakan dalam penelitian ini menggunakan metode kualitatif. Penelitian kualititatif itu sendiri merupakan sebuah metode penelitian yang di gunakan untuk menggali suatu masalah dalam suatu fenomena, sedangkan menurut Bogdan dan Biklen, S. penelitian kualitatif salah satu metode penelitian yang menghasilkan data deskripsi dari ucapan hasil wawancara atau tulisan dan perilaku dari objek yang di amati. 
Sumber data primer dari penelitian ini merupakan hasil wawancara dari masyarakat dan pelaku pengimplementasian dalam mewujudkan Kampung Hijau Berseri, dalam pengambilan sampel wawancara menggunakan random sampel, sehingga responden yang menjadi informan menjadi kunci awal penelusuran. Dan data sekunder didapatkan dari internet termasuk dalam pencarian E-Jurnal dan E-Book.

Riset ini menggunakan instrumen penelitian berupa hasil wawancara dengan tokoh terkait dan lebar dokumentasi. Dalam pengambilan data penelitian ini menggunakan metode wawancara, observasi, dan dokumentasi keadaan di lapangan. Setelah mengumpulkan data dilakukan verifikasi ulang untuk mengecek keabsahan data yang telah didapatkan, dengan menggunakan teknik triangulasi.

Lokus dalam penelitian ini adalah Kp. Hiaju Berseri RW 03, Jakarta Pusat. Alasan peniliti memilih tempat ini karena memang memiliki data yang begitu komprehensif yang dibutuhkan dalam melengkapi data dalam penelitian ini.

\section{HASIL DAN PEMBAHASAN}

1. Pembangunan Paradigma dan Pertumbuhan Masyarakat

Pembangunan kualitas hidup dan kesejahteraan masyarakat sejatinya sangat di perlukan dalam sebuah pembangunan hal itu harus di dukung dari berbagai aspek ekonomi, budaya, sosial masyarakat dalam suatu kelompok atau lokasi tertentu, pembangunan kualitas hidup tidak hanya sebagai suatu keadaan kualitas hidup manusia menjadi lebih sejahtera namun juga harus di iringi dengan aspek yang lain, konsep Chamber mengenai empowerment memberikan paradigma baru dalam memberdayakan sumber daya manusia, penelitian ini kemudian mengacu kepada people centered (human growth) sebagai fokus pemberdayaan dengan memberikan kekuatan yang lebih agar masyarakat bisa lebih bnyak berperan dalam hasil pembangunan, hal itu di lakukan oleh AMPUTASI sebagai sebuah gerakan masyarakat dalam menumbuhkan kekuatan masyarakat dengan memberikan pengetahun melalui penyuluhan rutin oleh para RT setiap masing-masing wilayah, tercatat di RW. Cempaka Putih terdapat 18 RT yang bergerak untuk memberikan pelatihan dan penyuluhan turut membantu memberikan pengetahuan mengenai kebersihan lingkungan.

Awalnya kebersihan lingkungan memang di pelopori oleh bapak Aan sebagai ketua LMK (Lembaga Musyawarah Kelurahan) kemudian di bantu oleh kawan-kawan lain di sekitar rumah yang juga ingin menumbuhkan tanaman di sekitar pekarangan sehingga akhirnya merambah terhadap masyarakat yang lain dan menjadi di legalkan sebagai sebuah gerakan kebersihan masyarakat dan kemudian menjadi sebuah penyuluhan kebersihan yang sustainable sehingga menumbuhkan kehidupan masyarakat dengan paradigma baru, yang tadinya konsep "membuang sampah pada 
tempatnya" menjadi "mengelola sampah sejak dari rumah" kemudian di keluarkan dari rumah di masukan kedalam kotak-kotak yang telah di sediakan oleh panitia AMPUTASI hal itu kemudian menjadi sebuah kebiasaan bagi masyarakat.

Tindakan yang di lakukan oleh AMPUTASI mengenai sampah ternyata memberikan dampak besar terhadap pengurangan sampah ke TPA tercatat sampah di Jakarta setiap hari di produksi sebanyak 7000 ton yang masuk ke TPA hal itu kemudian menjadi sebuah catatan penting bagi pemerintah daerah untuk melakukan tindakan mengurangi sampah yang harus melibatkan masyarakat maka AMPUTASI di RW. 3 Cempaka Putih melakukan upaya pengurangan sampah dan berhasil mengurangi sampah sebanyak 10\% kemudian di susul oleh RW lain di sekitar Cempaka Putih untuk melakukan tindakan yang sama.

Keberhasilan tindakan mengurangi sampah oleh AMPUTASI ternyata memberikan keberhasilan dalam hal lain, pasalnya kebiasaan masyarakat dalam mengelola sampah sejak dari rumah ternyata menjadi kebiasaan bersih bagi masyarakat dan mulai merambah pada gerakan lain yang juga diikuti oleh organisasasi lain yang terlibat yang banyak melibatkan orang, gerakan tersebut disusul dengan pemberdayaan lain:

\section{A. Pembuatan Biopori}

pembuatan biopori sebagai peresapan air berguna menangkap air hujan yang turun sehingga air hujan tidak kabur ke berbagai tempat dan fokus pada satu titik masuk ke dalam tanah sehingga menambah air tanah dan berguna bagi kelangsungan air untuk kehidupan masyarakat Kampung Hijau di RW. 3 dan menambah kesehatan tanah, biopori di buat secara vertical teknologi sederhana ini mulai di kembangkan di susul setelah adanya gerakan pengurangan sampah, selain berguna untuk menangkap genangan air, menurut penemunya sendiri Kamir. R. Brata mengatakan bahwa biopori biasanya di buat dengan ukuran lubang sedalam $80-100 \mathrm{~cm}$ untuk mengurangi genangan air hujan dan membantu meresapkan air tanah (Hilmawa tullisan, 2011)

\section{B. Bank Sampah}

Bank sampah di Kampung Hijau berseri sangat mirip dengan penelitian Donna Asteria dan Heru Heruman dalam Jurnalnya yang berjudul "Waste Banks as an Alternative of CommunityBased Waste Management Strategy in Tasikmalaya" konsep Bank sampah harus dengan empat basic principles yaitu reduce, reuse, recycle dan replant(4R) hal itu dilakukan dengan memberikan keterampilan kepada masyarakat untuk dapat mengelola sampah dengan konsep baru bahwa sampah tidak lagi di buang namun di olah maka akan menyelesaikan masalah sampah sejak dari sumbernya secara langsung (Donna, 2015), begitu juga dengan aktifitas masyarakat di Kampung Hijau Berseri melakukan kegiatan pengurangan sampah dengan mengelola sejak dari rumah dan di pilah menjadi lebih bernilai. 
Pemilahan sampah di lakukan sejak dari rumah, sampah non organik di jadikan pernah-pernak hiasan yang akan di gunakan dalam lingkungan masyarakat. Sedangkan sampah organic akan di jadikan sebagai kompos untuk tanaman-tanaman yang di urban farming.

Data pengurangan sampah dicatat tiap bulannya oleh setiap RT dilingkungan RW 03 dan nantinya akan di akumulasikan oleh pihak RW tiap bulannya. Berikut adalah Data penimbangan/Pengurangan sampah organik untuk komposter bulan September-Desember 2019 dan Bulan Januari-Maret 2020, RW 03, Kel. Cempaka Putih Jakarta Pusat.

\begin{tabular}{|c|c|}
\hline Bulan & $\begin{array}{c}\text { Pengurangan } \\
\text { Sampah 2019 }\end{array}$ \\
\hline Agustus & $22,025 \mathrm{Kg}$ \\
\hline September & $413,115 \mathrm{Kg}$ \\
\hline Oktober & $1,374,480 \mathrm{Kg}$ \\
\hline November & $1,472,600 \mathrm{Kg}$ \\
\hline Desember & $1,397,670 \mathrm{Kg}$ \\
\hline $\begin{array}{c}\text { Akumulasi } \\
\text { keseluruhan }\end{array}$ & $4,679,890 \mathrm{Kg}$ \\
\hline
\end{tabular}

Tabel. 1 Data Pengurangan sampah untuk komposter tahun 2019

\begin{tabular}{|c|c|}
\hline Bulan & Pengurangan Sampah \\
\hline Januari & $881,180 \mathrm{Kg}$ \\
\hline Februari & $691,910 \mathrm{Kg}$ \\
\hline Maret & $709,225 \mathrm{~kg}$ \\
\hline $\begin{array}{c}\text { Akumulasi } \\
\text { keseluruhan }\end{array}$ & $4,679,890 \mathrm{Kg}$ \\
\hline
\end{tabular}

Tabel. 2 Data Pengurangan sampah untuk komposter tahun 2020

Tabel 1 dan 2 berisi data dari sampah organic yang di konversi menjadi sesuatu yang lebih bermanfaat dalam hal ini adalah komposter. Berikut ini merupakan data dari sampah non organik yang ditimbang dan masuk dalam bank sampah dari masing-masing kelompok bank sampah yang ada dilingkungan RW 03 Kel. Cempaka Putih. Karena bank sampah ini sifatnya tidak di Secara individu dikelolanya tapi berkelompok. Nantinya dari hasil penimbangan dananya akan digunakan untuk kepentingan bersama.

\begin{tabular}{|c|c|}
\hline Nama Sampah & $\begin{array}{c}\text { Hasil } \\
\text { Penimbangan }\end{array}$ \\
\hline Botol Bersih & $40 \mathrm{~kg}$ \\
\hline Gelas Bersih & $2,5 \mathrm{~kg}$ \\
\hline Gabruk & $5 \mathrm{~kg}$ \\
\hline Kaleng & $1 \mathrm{~kg}$ \\
\hline Tutup botol & $2,5 \mathrm{~kg}$ \\
\hline Alumunium & $0,5 \mathrm{~kg}$ \\
\hline Emberan & $1 \mathrm{~kg}$ \\
\hline Kardus & $50 \mathrm{~kg}$ \\
\hline Akumualsi & $102,5 \mathrm{~kg}$ \\
\hline
\end{tabular}

Tebel 3. Penimbangan Sampah An Organik untuk Bank Sampah Kelompok Srikaya Bulan April 2020

\begin{tabular}{|c|c|}
\hline Nama Sampah & $\begin{array}{c}\text { Hasil } \\
\text { Penimbangan }\end{array}$ \\
\hline Botol Bersih & $24,5 \mathrm{~kg}$ \\
\hline Gelas Bersih & $1 \mathrm{~kg}$ \\
\hline Gabruk & $23 \mathrm{~kg}$ \\
\hline Kaleng & $5 \mathrm{~kg}$ \\
\hline Akumualsi & $27,5 \mathrm{~kg}$ \\
\hline
\end{tabular}

Tebel 4. Penimbangan Sampah An Organik untuk Bank Sampah Kelompok Pucuk Merah Bulan April 2020

Jika dilihat dari data maka Linkungan Cempaka Putih di Jakarta Pusat layak untuk dijadikan kampung 
percontohan untuk daerah Jakarta lainnya. Jika semua orang memiliki kesadaran yang sama seperti kelompok AMPUTASI yang bergerak di Cempaka Putih untuk membuat kampung hijau berseri dengan cara mengkonversi sampah menjadi sesuatu yang lebih berharga entah komposter atau bank sampah, bukan tidak mungin DKI Jakarta perlahan akan terhindar dari banjir.

\section{Tanaman Kota (urban farming)}

Urban farming sebagai sebuah bentuk pemanfaatan lahan sempit gang di RW. 3 Cempaka Putih maka di lakukan di gang-gang sempit tersebut dan lahan tidur miliki pemerintah daerah, sebagai sebuah instruksi khusus. Menggunakan lahan tidur adalah salah satu pilihan tapi umumnya Urban Farming di lakukan oleh masyarakat Kampung Hijau Berseri berada di teras rumah, balkon, dan atap-atap bangunan, namun ketiadaan tanah menjadi salah satu hambatan untuk menanam di tengah kota maka salah satu metode yang di gunakan oleh AMPUTASI yaitu dengan mengembangkan Hydrionik.

Tanamanya sendiri biasanya terdiri dari tanaman yang serba ringan seperti sayuran, tanaman obat, Toga, Markisa, Kunyit, Tanaman Hias, Cincau atau bahkan tanaman dari luar negeri karena menurut mereka tanaman biasa sudah terlalu banyak dan untuk menarik para pengunjung yang datang ke Kampung Hijau maka perlu adanya inovasi baru mengenai tanaman yang di kembangkan.

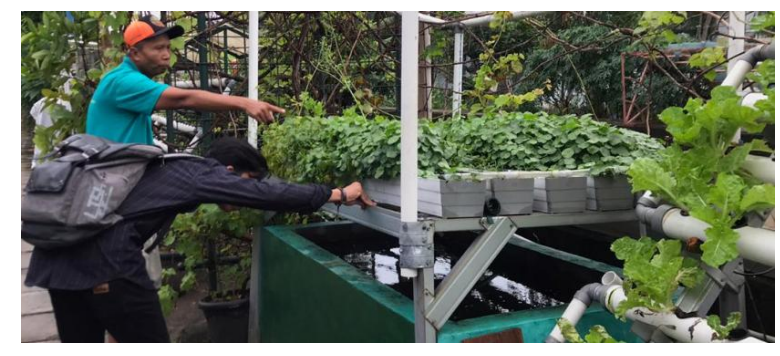

Gambar 1. Hydroponik yang di buat oleh

P4S untuk menanam Tanaman Kota

\section{Kelompok Ikan}

Perkotaan seperti Jakarta tentu saja membutuhkan banyak sekali kebutuhan dasar sebagai konsep empowerment, Chamber memenuhi kebutuhan masyarakat sebagai basic needs, tentu saja ini di lakukan oleh masyarakat Kampung Hijau Berseri selain menanam Tanaman Kota sebagai konsep aksi masyarakat tentu saja melakukan hal lain untuk memenuhi kebutuhan dasar tersebut maka di buatlah aksi kelompok ikan sebagai cara lain memberdayakan masyarakat. Kemudian aktifitas itu juga di bantu oleh pemerintah DKI dengan memberikan ikan atau berupa peralatan seperti kolam atau alat pernapasan ikan untuk memutar air secara otomotis.

Kelompok ikan ini di lakukan di pinggir-pinggir rumah warga guna mengurangi wilayah yang tidak terpakai sehingga di buat-buat lubang sesuai dengan yang di contohkan oleh pengurus AMPUTASI sehingga memberikan dampak yang jauh lebih besar terhadap masyarakat sehingga mengurangi angka pembelian kebutuhan dasar ke pasar. 


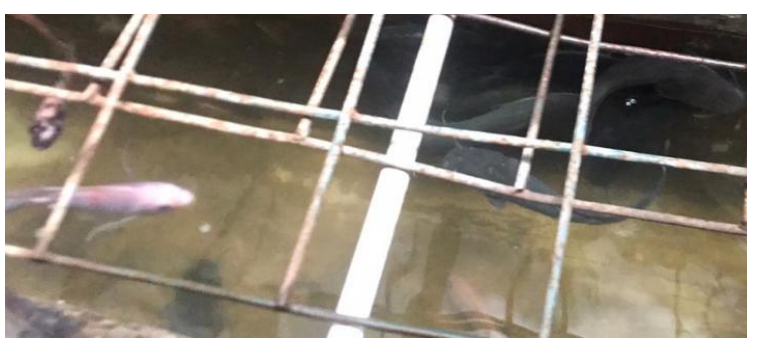

Gambar 2. Kolam Ikan masyarakat

Kampung Hijau Berseri.

\section{Peranan Stakeholder dan Perangkatnya}

Pembentukan

suatau

kebudayaan baru tentu saja akan membutuhkan waktu yang lama karena hal itu berkaitan dengan kebiasaan masyarakat yang sudah terbiasa dengan kehidupan mereka sehari-hari, dalam hal ini tentu saja mewujudkan Kampung Hija Berseri perlu adanya percontohan yang lebih serius dari peran kelembagaan yang ada, sebab faktor kelembagaan dalam struktur masyarakat sangat penting untuk mengendalikan masyarakat (Adian, 2020)

$$
\text { Dalam }
$$

memberikan

pemahaman mengenai proses penanaman pohon obat atau buahbuahan produktif di dalam lingkungan perkotaan misalnya tentu saja membutuhkan penyuluhan yang akan di lakukan sehingga peranan lembaga seperti RT, RW, Kelurahan, Kecamatan, Karang Taruna, LMK, PKK dan organisasi masyarakat yang di libatkan dalam penyuluhan mengenai kebersihan lingkungan menjadi sangat penting sebagai orang yang akan memberikan contoh terhadap masyarakat karena masyarakat tidak bisa hanya sekedar di ajak tapi benarbenar harus di contohkan dengan di perlihatkan secara langsung sehingga masyarakat bisa menyaksikan dan meniru apa yang di lakukan para lembaga tersebut dalam memberikan contoh (Adian, 2020)

Mengenai soal mengajak masyarakat dalam melakukukan tindakan kebersihan lingkungan pernah juga di lakukan oleh Kepala Desa Kayu Putih memberikan pemaknaan bahwa mengajak masyarakat untuk peduli terhadap lingkungan jelas tidak cukup namun memulai langkah peduli terhadap lingkungan harus di mulai oleh para stakeholder terlebih dahulu sehingga masyarakat dapat mencontoh apa yang di lakukan oleh kepala desa Kayu Putih. (Rati, 2014)

Peranan stakeholder dalam proses penanaman kebudayaan dalam masyarakat mengenai lingkungan juga penting dalam pembuatan peraturan, jelas tidak hanya sekedar penyuluhan namun dengan di buatnya peraturan lingkungan sekitar gang di RW. 3 Kampung Hijau juga sangat mempengaruhi sekali kaerna akan berkaitan dengan ketaatan, dan kebiasaan masyarakat Kampung Hijau Berseri, hal lain juga di lakukan instruksi dan ajakan dengan menempelkan kayu papan dalam ganggang mengenai instruksi membuang sampah pada tempatnya, mendorong melakukan pola hidup bersih, mengajak menanam tanaman produktif di sekitar gang RT, memilah sampah sejak dari rumah, menempatkan sampah kepada tempat yang sudah di sediakan panitia 
AMPUTASI lalu proses, memberikan pakan ikan dengan sisa makanan.

$$
\text { Adapun selain peranan }
$$
stakeholder yang ada di daerah RW. 3 juga di bantu oleh Pemeritah Provinsi DKI dengan di buatnya instruksi Provinsi DKI untuk di buatnya pertanian perkotaan yang tercantum dalam Instruksi Gubernur Provinsi Daerah Khusus Ibukota Jakarta, No. 14 Tahun 2018 tentang Pelaksanaan Pertanian Perkotaan dengan sangat jelas adanya instruksi ini membantu stakeholder yang di DKI untuk melaksanakan instruksi tersebut sehingga akan di breakdown kedalam pelaksana tugas-tugas bagi organisasiorgansiasi masyarakat dan NGO seperti P4S (Pusat Pelatihan Pertanian, Pedesaan, Swadaya), AISEC (Association Internationale des Etudiants en Sciences Economiques et Commerciales), program Sampah milik bersama (SAMTAMA), Gerakan Nasional Program Kampung Iklim (PROKLIM), Forum Masyarakat Peduli Lingkungan (FORMAPEL), HKTI (Himpunan Kerukunan Tani Indonesia), KP3 DKI (Komunitas Pertanian Perkotaan Provinsi DKI) secara khusus di Cempaka Putih RW. 3 mereka ikut serta mendorong terbentuknya budaya kebersihan masyarakat RW. 3 dengan melakukan kebershihan lingkungan seperti menanam tanaman kebun, menjadikan pupuk organic, biopori sebagai resapan air, peliharaan ikan, Hydroponik, Bank sampah, pembuatan kompos, budidaya magot dan dengan mendorong para RT yang bejumlah 18 RT yang tersebar di RW. 3 sangat massif dalam memberikan informasi dengan penyuluhan yang rutin setiap satu bulan sekali di lakukan di lingkungan Kampung Hijau Berseri (Adian, 2020), hal itu relevan dengan konsep envowerment Chamber yang bersifat participatory sebagai bentuk keterlibatan masyarakat dan segala perangkatnya maka tidak heran dengan perjalanan panjang yang di mulai sejak tahun 2007 sedikit demi sedikit kesadaran masyarakat terus tumbuh sehingga menciptakan kebiasaan baru dengan lingkungan RW. 3 yang jauh lebih bersih.

\section{Implikasi pencapaian AMPUTASI terhadap lingkungan Kampung Hijau Berseri}

AMPUTASI sebagai suatu aksi masyarakat yang tadinya hanya ingin memberikan lingkungan bersih bagi RW. 3 ternyata berkesinambungan terhadap implikasi lain sebab menciptakan kampung bersih tidak hanya menciptakan sanitasi yang baik, pengolahan sampah yang baik, atau hanya mengola tanaman di dalam gang namun banyak faktor yang yang harus juga di laksanakan, menurut WHO saja misalnya sebagai lingkungan bersih harus adanya keseimbangan ekologi di antara manusia dan lingkungan agar dapat menjamin keadaan sehat dari manusia.

Seperti yang dikatakan oleh Chamber bahwa dalam pemberdayaan masyarakat akan berdampak pada pembangunan ekonomi yang merangkum nilai-nilai masyarakat. Setelah terjadinya gerakan dalam hal pembedayaan masyaarkat untuk peduli terhadap lingkungan, dampak yang ditimbulkan terhadap lingkungan 
kampung hijau berseri adalah terciptanya lingkungan yang hijau dan asri serta lebih sehat.

Lingkungan yang hijau dan asri memiliki dampak dominio pada pola kehidupan masyarkat, setidaknya ada empat dampak yang di timbulkan, yaitu: Pertama, masyarkat lebih sadar terhadap lingkungan, ini terlihat dari sampah dapur yang mereka pilah terlebih dahulu sebelum mereka buang. Kedua, Masyarakat bisa lebih memahami pola serapan air. Dimana hal ini bisa dijadikan bahan percontohan kampung-kampung atau lingkungan-lingkungan di DKI Jakarta dalam perekayasaan air, karena persoalan tiap tahun DKI adalah soal banjir, debit air yang tinggi tidak bisa ditampung oleh sungai-sungai yang ada di Jakarta. Solusi lainnya adalah air tersebut perlu di resapkan kedalam tanah. Ketiga, masyarat lebih ekonomis karena dalam melakukan pembelanjaan dapur, sebagian bahan dapur sudah ada dan tersedia di lingkungan kampung, seperti ikan dan sayuran hijau. Keempat, masyarakat akan lebih paham soal urban farming. Ternyata pertaniaan hijau tidak hanya bisa dilakukan di pedesaan saja tetapi juga bisa dilakukan di perkotaan dengan konsep urban farming.

Dampak lainnya yang ditimbulkan adalah masyarakat lebih peduli terhadap program kerja pemerintah. Pemerintah daerah DKI memiliki program kerja yang namanya SAMTAMA (sampah milik bersama) dengan adanya kampung hijau berseri ini program Pemda DKI secara tidak langsung terimplementasikan oleh masyarakat tanpa harus ada stimulus yang begitu rumit dari pemerintah kepada masyrakat. Kampung Hijau Berseri bahkan sangat di apresiasi oleh Gubernur DKI. Hampir tiap tiga bulan sekali Guebrnur DKI datang untuk mengunjungi kampung tersebut.

Dalam sisi edukatif lingkungan tersebut sangat memberikan dampak, ini terbukti dengan seringnya kunjungan para pelajar dan mahasiswa baik lokal, nasional, maupun internasioanl berkunjung ke kampung tersebut, guna mencari tahu tentang pengelolaan sampah dan membuat kampung hijau di perkotaan. Bahkan tiap tahunnya ada saja mahasiswa luar negri yang berkunjung ke kampung tersebut. Dampak untuk warga lingkungan sekitar adalah kebanggaan yang tumbuh dalam diri warga kampung hijau berseri, sehingga mereka akan senantiasa menjaga kampung hijau berseri.

\section{E. SIMPULAN DAN SARAN \\ 1. Simpulan}

Gerakan AMPUTASI di Kampung Hijau Berseri memberikan dampak positif yang besar bagi lingkungan. Bahkan mendapat apresiasi dari berbagai kalangan. AMPUTASI sebagai sebuah gerakan masyarakat dalam menumbuhkan kekuatan masyarakat dengan memberikan pengetahun melalui penyuluhan rutin oleh para RT setiap masing-masing wilayah, dan tercatat di RW. Hal ini dapat membentuk konstruksi paradigma masyarakat yang mulai sadar akan lingkungan. Sehingga gerakan yang dilakukan ini 
dapat membuat lingkungan lebih asri dan hijau serta lebih produktif. Hal ini dikarenakan fokus gerkan ini lebih di arahkan pada penghijauan dan pengurangan sampah di Kampung Hiaju Berseri. Gerakan pengurangan sampah ini juga bersinergis dengan kegiatan lingkungan lainnya yang lebih produktif seperti: pembuatan pupuk organik hasil dari konversi sampah organic, dan bank sampah yang menjadi wadah penampungan sampah non organik, semua itu dilakukan agar membuat sampah yang ada lebih memiliki nilai ekonomis, serta dampak utamanya adalah berkurangnya sampah di lingkungan Kampung Hiaju Berseri.

Gerkan AMPUTASI di kampung Hijau Berseri juga sejalan dengan program pemerintah DKI yaitu SAMTAMA (sampah milik bersama), selain itu gerkan ini berdampak pada pembutan biopori di lingkungan kampung Hijau berseri, bank sampah, dan tanaman pertanian kota (urban farming), serta dibentuknya kelompok budi daya ikan di kampung Hijau Berseri.

\section{Saran}

Berdasarkan hasil observasi, studi lapangan, wawancara, dan juga kajian literatur yang dilakukan oleh peneliti. Maka peneliti memiliki beberapa saran yang tentunya saran ini bertujuan untuk membangun ide dan gagasan kearah yang lebih baik lagi, yaitu;

Pertama, langkah yang masih harus dilakukan oleh masyarakat Kampung Hijau berseri agar semakin dapat menciptakan lingkungan yang hijau dan asri adalah terus melakukan campaign tentang bagimana membuat lingkungan sehat, dan langkah-langkah persuasif lainnya yang dapat membuat masyarakat semakin tertarik untuk mengelola sampah.

Kedua, dalam membangun kampung yang asri dan hijau, tidak hanya sekedar dengan cara mengelola sampah agar kampung tidak terlihat kotor, namun diperlukan juga perawatan tanaman yang lebih ekstra, sehingga masih diperlukan kesadaran kolektif untuk saling menghijaukan seminimalnya pekarangan rumah masing-masing. Dengan demikian kampung tidak hanya bersih dari sampah dan terlihat hijau, namun udara yang tersedia bisa lebih segar.

Ketiga, saran ini ditujukan kepada pemerintah DKI Jakarta yang memiliki program SAMTAMA (sampah tanggung jawab bersama). Dalam merealisasikan program tersebut sebaiknya untuk melakukan sosialisasi kesetiap kampung-kampung di Jakarta (bisa melalui RW) dan dalam sosialisasi tersebut bisa menggunakan nama Kampung Hijau Berseri sebagai salah satu contoh kampung yang berhasil dalam menangani sampah di DKI Jakarta, agar kampung yang lain memiliki role model untuk dijadikan acuan dalam mengimplementasikan SAMTAMA.

\section{DAFTAR PUSTAKA}

Aan,

Ketua

Lembaga

Musyawarah Keluruahan, Wawancara, Jakarta, Maret 2020. 
Adian,

Ketua Pusat Pelatihan Pertanian, Pedesaan, Swadaya, Wawancara, Jakarta, Maret 2020.

Asteria, D., \& Heruman, H. (2016). BANK SAMPAH SEBAGAI ALTERNATIF STRATEGI PENGELOLAAN SAMPAH BERBASIS MASYARAKAT DI TASIKMALAYA (Bank Sampah (Waste Banks) as an Alternative of Community-Based Waste Management Strategy in Tasikmalaya). Jurnal Manusia Dan Lingkungan, 23(1), 136. https://doi.org/10.22146/jml.1 8783

Dinas Kesehatan. (2015). Menciptakan Lingkungan yang Bersih dan Sehat (pp. 1-7). Diakses dari: https://lamongankab.go.id/din kes/menciptakan-lingkunganyang-sehat-dan-bersih/

Gubernur Provinsi DKI Jakarta. (2018). Instruksi Gubernur Provinsi DKI Jakarta Nomor 14 Tahun 2018 tentang Pelaksanaan Pertanian Perkotaan.

Hadi, A. P. (2015). Konsep pemberdayaan, partisipasi dan kelembagaan dalam pembangunn. Pusat Pengembangan Masyarakat Agrikarya, 1987, 1-14.

Hilwatullisan. (2011). Lubang Resapan Biopori (Lrb) Pengertian Dan Cara Membuatnya Di Lingkungan Kita. Media Teknik, Vol. 8(No. 2), Hal. 1-11.

Hikmawan, M. D. (2017). Pluralisme Demokrasi Politik di Indonesia. Journal of Governance, 2(2),
223-247.

https://doi.org/http://dx.doi.or g/10.31506/jog.v2i2.2678

Hikmawan, M. D., \& Hidayat, R. (2016). Depoliticisation of Public Issue : Low Degree of Government ' S Democratic Legitimacy. Journal of Governance, 1(1), 23-37. https://doi.org/http://dx.doi.or g/10.31506/jog.v1i1.1311

Hikmawan, M. D., Indriyany, I. A., \& Mayrudin, Y. M. (2019). Environmental Movement Against Mining Exploration in Bojonegara Serang Banten. https://doi.org/https://doi.org /10.2991/icdesa-19.2019.57

Plastik, B. S. (n.d.). Mewujudkan desa kayuputih sebagai model desa hijau bebas sampah plastik. 4 .

PROYEK AIR MINUM - Konstruksi Jatiluhur 1 \& Karian 2019. (n.d.).

Rao, U. (2019). Global cities. The Routledge Handbook of Transregional Studies, November, 188-196. https://doi.org/10.4324/97804 29438233-24 